\title{
ПОСТУПЛЕНИЕ РАДИОАКТИВНОГО ЙОДА В АТМОСФЕРУ ПРИ НОРМАЛЬНОЙ ЭКСПЛУАТАЦИИ АЭС
}

\author{
Назарович А.В. ${ }^{1}$, Пышкина М.Д. ${ }^{2}$, Десятов Д.Д. ${ }^{1}$, Екидин А.А. ${ }^{2}$
}

1) Уральский федеральный университет имени первого Президента России

Б.Н. Ельцина, Екатеринбург, Россия

2) Институт промышленной экологии, Екатеринбург, Россия

E-mail: kolalls26@mail.ru

\section{RELEASE OF RADIOACTIVE IODINE IN THE ATMOSPHERE DURING NORMAL OPERATION OF A NPP}

\author{
Nazarovich A.V. ${ }^{1}$, Pyshkina M.D. ${ }^{2}$, Desyatov D.D. ${ }^{1}$, Ekidin A.A. ${ }^{2}$ \\ 1) Ural Federal University, Yekaterinburg, Russia \\ 2) Institute of Industrial Ecology, Yekaterinburg, Russia
}

The analysis of data on emissions and discharges for the period from 2005 to 2018 of iodine isotopes for 68 US nuclear power plants with reactor of the PWR and BWR type.

Атомная энергетика является важнейшей подотраслью глобальной энергетики и составляет около $11 \%$ производимого в мире электричества. В 30 странах эксплуатируется более четырехсот ядерных реакторов на АЭС с общей мощностью около 380 гигаватт электрической энергии [1]. С развитием ядерной энергетики возрастает интерес к проблеме охраны окружающей среды от радиоактивного загрязнения. Это в свою очередь ведет к необходимости исследования закономерностей поведения радиоактивных изотопов в атмосфере, которые являются родоначальником миграции многих радионуклидов [2].

В результате выгорания топлива АЭС образуются сотни продуктов деления, среди которых выделяют изотопы йода: ${ }^{131} \mathrm{I},{ }^{132} \mathrm{I},{ }^{133} \mathrm{I},{ }^{135} \mathrm{I},{ }^{130} \mathrm{I},{ }^{134} \mathrm{I},{ }^{123} \mathrm{I},{ }^{129} \mathrm{I}$, некоторые из которых в свою очередь определяют дозовую нагрузку на население и входят в перечень радионуклидов, в отношении которых применяются меры государственного регулирования в области охраны окружающей среды при выбросах и сбросах в атмосферу [3].

В данной работе анализируются показатели производства электроэнергии, удельные показатели выбросов и сбросов радиоактивного йода АЭС США за период с 2005 по 2018 г., что позволяет выявить типы реакторов с наилучшей практикой применения методов и технологий, которые минимизируют поступление радиоактивного йода в окружающую среду при нормальной эксплуатации.

1. International Atomic Energy Agency. Indicators for Nuclear Power Development Nuclear Energy Series No. NG-T-4.5 Technical Reports. Vienna: IAEA, 2015.

2. Екидин А.А., Васильев А.В., Васянович М.Е. // Биосферная совместимость: человек, регион, технологии. 2017. № 2 (18). С. 67-74. 
3. Перечень загрязняющих веществ, в отношении которых применяются меры государственного регулирования в области охраны окружающей среды: Распоряжение Правительства РФ N 1316-р от 08.07.2015. М., 2015 (с изменениями на 10 мая 2019 года).

\title{
МОЛИБДЕН В ВЫСОКОЩЕЛОЧНЫХ БОРОСИЛИКАТНЫХ СИСТЕМАХ
}

\author{
Неволина Л.А. ${ }^{1,2}$, Еремяшев В.Е. ${ }^{1,2}$, Кориневская Г.Г. ${ }^{2}$ \\ 1) Южно-Уральский государственный университет, Челябинск \\ ${ }^{2)}$ Институт минералогии ФГБУН ЮУ ФНЦ МиГ УрО РАН, Миасс \\ E-mail: eremiashevve@susu.ru
}

\section{MOLYBDENUM IN HIGH ALKALINE BOROSILICATE SYSTEMS}

\author{
Nevolina L.A. ${ }^{1,2}$, Eremyashev V.E. ${ }^{1,2}$, Korinevskaya G.G. ${ }^{2}$ \\ ${ }^{1)}$ South Ural State University, Chelyabinsk \\ ${ }^{2)}$ Institute of Mineralogy of the SU FRC of MG UB of the RAS, Miass
}

The influence of molybdenum oxide on the crystallization processes and the glass structure has been studied for the $\mathrm{Li}_{2} \mathrm{O}-\left(\mathrm{Na} 2 \mathrm{O}-\mathrm{K}_{2} \mathrm{O}\right)-\mathrm{B}_{2} \mathrm{O}_{3}-\mathrm{SiO}_{2}$ system. It has been established that molybdenum is slightly soluble in the glass structure and affect on the phase composition of samples.

Оксиды молибдена являются распространенным компонентом высокоактивных радиоактивных реакторных отходов, и их содержание в РАО, в зависимости от генезиса отходов, может достигать 15 мас.\%. Применение технологии остекловывания для отходов с высоким содержанием молибдена с использованием матриц на основе алюмоборосиликатных стекол обладает рядом особенностей, так как растворимость молибдена в боросиликатных и алюмоборосиликатных стеклах является низкой и носит ярко выраженную композиционную и структурную зависимость [1-3]. Высокое содержание $\mathrm{MoO}_{3}$ в составе боросиликатных материалов всегда сопровождается кристаллизацией молибденсодержащих фаз с различной гидротермальной устойчивостью.

В соответствии с выявленным значительным интересом кристаллизационным процессам в молибденсодержащих боросиликатных системах нами были выполнены синтез и исследование структуры, фазового состава и термических свойств высокощелочных молибденсодержащих натриево-литиевых и калиеволитиевых боросиликатных стеклокерамических материалов.

Проведенные исследования показали, что при высоком содержании молибдена боросиликатные материалы, полученные закалкой расплава, демонстрируют в значительной степени стеклообразное состояние. Отличительной особенностью поведения молибдена в этих боросиликатных системах является его незначительно участие в формировании сетки стекла. Практически весь молибден, 